2. Pastukhova Yu. A. Khudozhno-estetychne vykhovannia studentskoi molodi $\mathrm{v}$ tsilisnomu pedahohichnomu protsesi universytetu / Yuliia Anatoliivna Pastukhova: Avtoref. Dys. kand. nauk: 13.00.07. - teoriia ta metodyka vykhovannia. - Luhansk, 2009. $-20 \mathrm{~s}$.

3. Rostovtsev N. N. Ocherky po ystoryy metodov prepodavanyia rysunka. - M., 1983. - s.184.

4. Sotska H. I. Estetychno-profesiina kompetentnist maibutnoho vchytelia obrazotvorchoho mystetstva Rezhym dostupu : http:/ /lib.iitta.gov.ua

5. Slastenyn V. O. Pedahohyka / V. O. Slastenyn. - M.: Prosveshchenye. - 1987. -362 s.

6. Nemov R. S. Psykholohyia : uchebnoe posobye / R. S. Nemov. - M. : Prosveshchenye. $-1990 .-301 \mathrm{~s}$.

7. Elektronnyi resurs. Rezhym dostupu - file://C:/Users $/ \% \mathrm{D} 0 \% \mathrm{~A} 2 \% \mathrm{D} 0 \% \mathrm{~B} 0 \% \mathrm{D} 0 \% \mathrm{BD} \% \mathrm{D} 1 \% 8 \mathrm{~F} /$ Downloads/Vznu_ped_2015_1_21.pdf

Одержано статтю: 12.06.2019

Прийнято до друку: 26.06.2019

УДК 371.211 .24

DOI: $10.15330 /$ esu. 16.97-102

\section{Яна Лацівська,} аспірантка, Східноєвропейський національний університет імені Лесі Українки (м. Луцьк, Україна) Yana Laschivska,

Post-graduate student, Eastern European National University Lesya Ukrainka (Lutsk, Ukraine) lashchivskayana@ukr.net

\title{
ПРОФЕСІЙНА МАЙСТЕРНІСТЬ ЯК ОСНОВНИЙ КОМПОНЕНТ ПЕДАГОГІЧНОӤ КУЛЬТУРИ
}

\section{PROFESSIONAL MASTERNESS AS THE BASIC COMPONENT OF PEDAGOGICAL CULTURE}

У статті розкриваються питання професійної майстерності майбутніх магістрів музичного мистечтва. Підкреслено, що професійно-педагогічна майстерність як наукова проблема грунтовно досліджується сучасними психологами, філософами, педагогами на теоретичному, експериментально-дослідному рівнях (обтрунтування сутності, складників майстерності, визначення й експериментальна перевірка умов, засобів ї формування точи).

Так, маючи глибокі сочіальні й історичні корені, проблема професійної майстерності майбутнього магістра музичного мистечтва, майбутнього педагога залииалась надзвичайно актуальною. Як відомо, витоки пї полягають в ідеях давнього риторичного мистецтва і безпосередній ораторській діяльності. Необхідним складником професійной майстерності майбутнього магістра музичного мистечтва вчені досліджуваного періоду називали спечіальну, фундаментальну фахову підготовку.

Цілком очевидно, що вимоги до сучасного магістра музичного мистечтва повинні відповідати потребам сьогодення і передбачати: високий професіоналізм в обраній сфері; інновачійний характер мислення і готовність до змін. Разом з тим висококваліфікований магістр музичного мистечтва повинен володіти основними етичними нормами та правилами поведінки у ділових відносинах. Водночас необхідно розвивати і сочіальнопсихологічні навички діяльності майбутнього магістра музичного мистечтва, які мають базуватися на знанні засад формувания організачійної культури, реалізачії принципів розвитку сочіальних відносин, традииій, звичайв. Адже духовність, культура, інтелігентність с невід'смними складовими професіоналізму майбутнього магістра, особливо коли його діяльність пов 'язана з людьми. Професійна майстерність майбутнього магістра музичного мистеитва має формуватись у процесі здійснення методичного забезпечення навчального прочесу в закладах освіти різного типу. 
Ключові слова: професійна майстерність, майбутні магістри музичного мистечтва, кваліфікована освіта, навчальні заклади.

The article reveals the issues of professional mastery of future masters of musical art. It was emphasized that professional-pedagogical skill as a scientific problem is thoroughly investigated by modern psychologists, philosophers, teachers at theoretical, experimental-research levels (substantiation of essence, components of skill, definition and experimental verification of conditions, means of its formation, etc.).

So, having deep social and historical roots, the problem of teacher-teacher pedagogical skills, the teacher remained extremely relevant. As you know, its origins consist of the ideas of ancient rhetorical art and direct oratory activity. Necessary component of vocational and pedagogical skills teachers teachers of the studied period called special, fundamental professional training.

It is clear that the requirements for a modern master of music art must meet the needs of the present and predict: high professionalism in the chosen field; innovative thinking and readiness for change. However, a highly skilled master of music art must possess the basic ethical norms and rules of conduct in business relations. At the same time, it is necessary to develop the sociopsychological skills of the future master of musical art, which should be based on the knowledge of the principles of the formation of organizational culture, the implementation of the principles of development of social relations, traditions, customs. After all, spirituality, culture, and intellectuality are integral components of the future Master's professionalism, especially when its activities are connected with people. The professional mastery of the future master of music art should be formed in the process of implementing methodological provision of the educational process in educational institutions of various types.

Key words: professional skills, future masters of musical art, qualified education, educational institutions.

Постановка проблеми. Сучасні навчальні заклади готують фахівців, які володіють не тільки фаховими знаннями, уміннями, навичками і системним, аналітичним, прогнозним стилем мислення, але й високою морально-етичною та професійною культурою. Адже саме вища освіта $є$ вагомим чинником становлення та розвитку молодого покоління. Педагогічна культура як вищий рівень педагогічної майстерності, педагогічної освіченості, професійної компетентності й людської індивідуальності формується в процесі професійної діяльності (А. Барабанщиков, Б. Гершунський, С. Муцинов, М. Скрипник, В. Сухомлинський та ін.).

Аналіз останніх наукових досліджень. Глибокому теоретичному усвідомленню проблеми формування професійної майстерності викладачів В3О України ХІХ - початку XX ст. сприяло вивчення робіт А.М.Алексюка, В.О.Глузмана, М.Б.Євтуха, С.Т.Золотухіної, Н.С.Побірченко, М.Г.Стельмаховича, О.В.Сухомлинської тощо.

У наш час проведені дослідження, в яких розкривається теоретичний аспект формування професійної майстерності викладача, зокрема, сутність, складники професійної майстерності майбутнього вчителя (Б.Т.Ананьєв, Л.І.Божович, І.Д.Бех, I.І.Давидов, І.С.Кон, О.О.Леонтьєв, Н.М.Тарасєвич та ін.). Теоретичне осмислення професійної майстерності, 朵 становлення та розвиток здійснено I. Зязюном, Н. Кузьміною, А. Макаренком, В. Семиченко, В. Сухомлинським, Н. Тарасевич.

Мета статті - обгрунтувати сутність поняття "професійна майстерність" та чинників її формування у майбутніх магістрів музичного мистецтва.

Виклад основного матеріалу. За визначенням К.М.Хоруженко, термін "nрофесійна майстерність" застосовується в соціології та культурології для характеристики соціально-професійної якості суб'єкта праці і являє собою рівень 
оволодіння працівниками досягненнями науки й техніки, що є особистісним аспектом культури праці. Основними елементами професійної культури є освіта, професійний досвід і кваліфікація працівника [9, с. 239-240].

На думку А.І.Кравченка, під професійною майстерністю розуміють сукупність спеціальних теоретичних знань та практичних умінь, пов'язаних 3 певним видом праці. Ступінь оволодіння професійною культурою визначається у кваліфікації та кваліфікаційному розряді. При цьому розрізняють формальну та реальну кваліфікацію: перша пропонує необхідні для професії теоретичні знання, а друга практичні навики та вміння, професійний досвід, отриманий протягом декількох років роботи в даній галузі [3, с. 57].

Разом 3 тим чимало учених, зокрема М.М.Корінний та В.Ф.Шевченко, визначають сутність феномену професійної майстерності як відповідний рівень та якість професійної діяльності, котрі залежать від соціально-економічного стану суспільства й сумлінності особистості в оволодінні певними знаннями, навичками конкретної професії та їх практичному використанні. Для формування і становлення професійної культури потрібні навчальні заклади, що дають кваліфіковану освіту. Адже високий рівень професійної культури $є$ ознакою розвинутого суспільства [2, c. 173].

А.М.Новиков професійну майстерність особистості розрізняє за рівнями сформованості професійних знань, навиків і сформованості операційних, тактичних, стратегічних професійних умінь; за рівнями оволодіння основними кваліфікаціями уміннями оволодіння комп'ютером, іноземними мовами, професійного спілкування, навиками маркетингу, організації реклами і збуту продукції тощо; за рівнями оволодіння естетичними, етичними, економічними, екологічними, правовими компонентами професійної культури [4, с. 22]. У якості суттєвих рис сучасної професійної майстерності М.Ю.Ананченко виділяє наявність спеціальних (у тому числі етичних) знань, умінь i навиків, нормативність, здібність до діалогу та

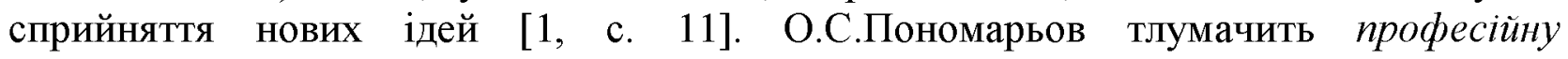
майстерність як обов'язковий елемент професіоналізму, "що грунтується на високій загальній і моральній культурі людини та іï духовності, й передбачає такий розвиток професійної компетентності фахівця у сфері його діяльності, який підносить цю діяльність та iї результати до рівня основних життєвих цінностей, завдяки чому формується почуття особистої відповідальності перед людьми і Богом за результати своєї діяльності, за можливі наслідки технічних чи управлінських рішень" [7, с. 92].

Як зазначає М.Пищулін, ще в античну добу Сократ і Платон обстоювали необхідність поєднання професіоналізму і моральності людини. На сьогодні ця вимога розглядається 3 точки зору формування освіченого, гуманного, духовного професіонала. Аналізуючи цю проблему, не можна не погодитися з думкою, що “гармонія і дисгармонія професійного розвитку представляє собою складну гаму поєднань необхідних для професійної діяльності якостей - від високої професійної та людської компетентності до повної професійної непридатності та моральної глухоти і нелюдськості" [6, с. 92-102].

Отже, готовність особистості до професійної діяльності в першу чергу визначається за критеріями професіоналізму i моральності: “моральна, але непрофесійна людина $є$ некомпетентною, оскільки друге без першого не в змозі забезпечити спеціалістові його самореалізацію. Не забезпечена професіоналізмом моральність, тим більше аморальний професіоналізм, гіпертрофують крайнощі добре безсилля і злу силу, замінюючи за правом сили перше другим” [6, с. 100]. 
Як бачимо, поєднання професійної і моральної культури - необхідні складові особистості сучасного професіонала. Моральна культура особистості майбутнього магістра розглядається як результат засвоєння особистістю морального досвіду, сформованого суспільством. У широкому вигляді вона представлена моральним досвідом особистості - системою переконань, ставлень, мотивів дій і відповідних моральних почуттів та стійких форм поведінки.

Слід зазначити, що професійна особистісна культура у широкому значенні тлумачиться як результат становлення особистості професіонала i $є$ тотожною всьому досвіду особистості, котрий забезпечує успішне виконання конкретної професійної діяльності та подальший розвиток професійної компетентності. У цьому значенні моральна культура особистості майбутнього магістра музичного мистецтва входить до складу професійної культури і визначається тією сукупністю особливих зобов'язань, що людина і громадянин приймає на себе, коли долучається до певної сфери професійної діяльності. У вузькому значенні під професійною культурою майбутнього магістра музичного мистецтва слід розуміти систему знань, умінь, навичок і здібностей, завдяки яким 'являсться можливість виконання тих трудових операцій і дій, що є необхідними у певній сфері професійної діяльності. Тобто йдеться про необхідний інструментальний рівень забезпечення праці. У такому розумінні професійна і моральна культура розглядаються як складові компоненти особистісної культури професіонала. Однак, незалежно від розуміння поняття, ми можемо зробити висновок, що висока моральна культура - необхідна якість професіонала у контексті гуманістичного розвитку суспільства. Саме вона $є$ основою для збагачення духовної складової тієї чи іншої професійної сфери, підвищення духовності суспільства [5, с. 47].

Аналіз психолого-педагогічних досліджень свідчить, що в цілому під професійною майстерністю майбутнього магістра музичного мистецтва слід розуміти комплекс спеціальних знань, умінь та навиків, володіючи якими фахівець певного виду праці стає майстром своєї справи, професіоналом. Варто зазначити, що на формування професійної культури майбутнього фахівця впливають як особливості самої професії, так і інші чинники. Серед них можна виділити загальну культуру майбутнього магістра музичного мистецтва. Має місце не лише вплив загальної культури майбутнього магістра музичного мистецтва на його професійну культуру, а й навпаки - вплив останньої на культуру його різнопланового спілкування поза виробничою сферою. Загальнокультурна підготовка, що включає в себе вивчення історії, економіки, права, соціології та політології, іноземної мови, культури мовлення тощо, $\epsilon$ фундаментом для професійного становлення. Вважається, шо формування загальної культури поведінки в цілому здійснюється в сім'ї. Проте важливу роль у формуванні професійної культури відіграють навчальні заклади, які створюють умови для професійного становлення, розвитку та самореалізації особистості. Адже, до чинників формування професійної культури майбутнього магістра музичного мистецтва слід віднести і культуру навчального закладу, де студент отримує теоретичні знання у вибраній сфері професійної діяльності, i культуру організацій, де проходить виробнича практика.

Цілком очевидно, що вимоги до сучасного магістра музичного мистецтва повинні відповідати потребам сьогодення і передбачати: високий професіоналізм в обраній сфері; інноваційний характер мислення і готовність до змін.

Разом 3 тим висококваліфікований магістр музичного мистецтва повинен володіти основними етичними нормами та правилами поведінки у ділових 
відносинах. Водночас необхідно розвивати і соціально-психологічні навички діяльності майбутнього магістра музичного мистецтва, які мають базуватися на знанні засад формування організаційної культури, реалізації принципів розвитку соціальних відносин, традицій, звичаїв. Адже духовність, культура, інтелігентність $\epsilon$ невід'ємними складовими професіоналізму майбутнього магістра, особливо коли його діяльність пов'язана з людьми.

Професійна майстерність майбутнього магістра музичного мистецтва має формуватись у процесі здійснення методичного забезпечення навчального процесу в закладах освіти різного типу. Так, розробки навчальних програм, підготовка посібників, методичних рекомендацій, курсів вимагали від авторів знань предмета, його специфіки, методики його викладання, вікових особливостей тих, хто навчається, тощо. Наприклад: якість посібників та підручників з різних предметів, рекомендації щодо роботи 3 ними; методика викладання класичних мов; методика оволодіння рідною мовою; розвиток творчої думки у процесі навчання, зокрема викладання музичних дисциплін; активізація інтересу до навчання, зокрема до конкретних предметів; застосування на заняттях різноманітних методів навчальнопізнавальної діяльності; формування мовленнєвої культури студентів тощо.

Висновки. Отже, передбачувана нами модель професійної діяльності майбутнього магістра музичного мистецтва може складатися 3 таких професійно-особистісних компонентів: комунікабельність; наполегливість, рішучість, впевненість у собі; творче мислення, активність та ініціативність; відповідальність, вимогливість, винахідливість; соціальна сміливість, рішучість; сила волі, емоційна стабільність.

На нашу думку, це далеко не всі якості, якими повинен володіти майбутній магістр музичного мистецтва. У професійному становленні майбутнього магістра музичного мистецтва першочергова увага повинна приділятися питанням етичної та музичної грамотності.

Зазначимо, що для формування професійної культури майбутнього магістра музичного мистецтва та поглиблення іiі професійного потенщіалу у вищих закладах освіти необхідні такі умови: забезпечення студентів фаховими та загальнотеоретичними знаннями; посилення гуманітарного та гуманістичного спрямування всіх навчальних предметів; впровадження спеціальних навчальних курсів, які сприятимуть формуванню професійної культури; забезпечення студентів відповідними базами практик; створення сприятливої морально-психологічної атмосфери у вищому навчальному закладі; впровадження новітніх технологій у навчальновиховний процес; впровадження соціально-педагогічного моніторингу як системи діагностики процесів формування компонентів професійної культури.

Перспективи подальших досліджень. Проведене дослідження не вичерпує багатогранності теоретичних i практичних пошуків розв'язання проблеми. Подальшого вивчення потребують проблеми, пов'язані зі структурою професійної майстерності майбутніх магістрів музичного мистецтва.

\section{Література}

1. Ананченко М.Ю. К вопросу о сущности и факторах становления профессиональной культуры специалиста. Формирование профессиональной культуры будущего специалиста: Материалы $\mathrm{X}$ областной студенческой научной конференции и международных педагогических чтений: Сб. статей и тез. Архангельск, 2003. С.11-14.

2. Корінний М.М., Шевченко В.Ф. Короткий енциклопедичний словник з культури. К., 2003. 384 c.

3. Кравченко А.И. Культурология. М., 2001. 372 с.

4. Новиков А. М. Российское образование в новой эпохе. М., 2002. 232 с. 
5. Палеха Ю.І. Ділова етика: навч. посібник. К., 2001. 238 с.

6. Пищулин Н.М. Формировать, воспитывать духовность. Педагогика толерантности. 2002. № 3. C.92-102.

7. Пономарьов О.С. Невідкладність проблем формування загальної професійної культури сучасних фахівців. Вищи иккла. 2002. № 6. С. 88-92.

8. Сливка С. Професійна культура юриста (теоретико-методологічний аспект). Л.: Світ, 2000. 119 c.

9. Хоруженко К.М. Культурология: Энциклопедический словарь. Ростов-на-Дону, 1997. С.239240.

\section{References}

1. Ananchenko M.Yu. On the question of the essence and factors of the formation of a professional culture specialist. Formation of professional culture of a future specialist: Materials of the $\mathrm{X}$ regional student scientific conference and international pedagogical readings: Sat. articles and abstracts. Arkhangelsk, 2003. September 11-14.

2. Korinny MM, Shevchenko V.F. A brief encyclopedia of culture. K., 2003. 384 p

3. Kravchenko AI Cultural Studies. M., 2001. 372 p.

4. Novikov AM, Russian Education in a New Era. M., 2002. 232 p.

5. Palekha Yu.I. Business Ethics: Teach. manual. K., 2001. 238 p.

6. Pishchulin N.M. To form, to cultivate spirituality. Pedagogy of Tolerance. 2002. No. 3. p.92-102.

7. Ponomarev O.S. Urgency of problems of formation of the general professional culture of modern specialists. High school. 2002. No. 6. P. 88-92.

8. Cream S. Professional culture of a lawyer (theoretical and methodological aspect). L.: World, 2000. $119 \mathrm{p}$.

9. Khorzhenko K.M. Cultural Studies: An Encyclopedic Dictionary. Rostov-on-Don, 1997. p.239-240.

Одержано статтю: 19.07.2019

Прийнято до друку: 02.08.2019

УДК:37.013

DOI: $10.15330 /$ esu. $16.102-109$

\author{
Анна Лякішева, \\ доктор педагогічних наук, професор, \\ Східноєвропейський національний університет \\ імені Лесі Українки (м. Луцьк, Україна), \\ Anna Liakisheva, \\ Doctor of pedagogical sciences, Professor, \\ Lesia Ukrainka Eastern European National University \\ (Lutsk, Ukraine) \\ lyakisheva.anna@eenu.edu.ua
}

\section{ПРОФЕСІЙНЕ САМОВИЗНАЧЕННЯ СТУДЕНТІВ ПЕДАГОГІЧНИХ ФАКУЛЬТЕТІВ: СУТНІСТЬ ТА СТРУКТУРА ПОНЯТТЯ}

\section{PROFESSIONAL SELF-DETERMINATION OF PEDAGOGICAL FACULTY STUDENTS: ESSENCE AND STRUCTURE OF THE CONCEPT}

У статті подано, що найважливішим критерісм усвідомлення $і$ продуктивності професійного становлення людини с й здатність знаходити особливий сенс в професійній прачі, самостійно проектувати, творити свое професійне життя, відповідально ухвалювати рішения про вибір професії, спеціальності і місче роботи. Ці проблеми постають перед особистістю на протязі всього ӥ̈ життя.

Перед людиною весь час виникають проблеми, ио вимагають від неї визначення свого ставления до професії, іноді апалізу і рефлексії власних професійних досягнень, ухвалення рімень про вибір професії або ї̈ заміну. Даний комплекс проблем 6 професіознавстві пояснюють поняттям професійне самовизначения. Варто звернути увагу, ио професійне самовизначення відбувається протягом всього життя особистості, зокрема протягом фахового навчання. 